\title{
Life history of Amara fulva (Coleoptera: Carabidae) in the southwest forest zone of the East European Plain
}

\author{
FELIX N. KOLESNIKOV and EKATERINA V. MALUEVA \\ Medical College 4 of Moscow Health Care Department, Moscow 123182, Russia; e-mails: f.kolesnikov@mail.ru; \\ ezhik-katyu@mail.ru
}

Key words. Coleoptera, Carabidae, Amara fulva, seasonal activity, life cycle, sex and age structure of population, overwintering distribution

\begin{abstract}
The patterns of seasonal activity, sex and age structure, reproductive characteristics and overwintering distribution of Amara fulva were studied in the southwest forest zone of the East European plain. A total of 1212 adults (664 males and 548 females) and 38 larvae were collected using pitfall traps. All adults were dissected to determine their reproductive condition. 185 larvae and 5 adults were collected by sampling soil. Adults of A. fulva were active from the first half of June until October with a single peak of activity in August. From June only postgenerative and newly emerged beetles were caught in traps. Immature and mature adults were recorded from the second half of July. At the end of August, more than $90 \%$ of the population was represented made up of mature adults. Immature individuals were trapped up until October after which they overwintered. Oviposition period lasted 11 weeks (from the mid-July to the end of September). Maximum number of mature eggs in ovaries was recorded in the second half of August. Larvae of $A$. fulva were caught from the second half of August to October and the peak in their subsoil activity was recorded in the first half of September. The life cycle of A. fulva is described as facultatively-biennial. Overwintering larvae and adults occurred in different parts of the floodplain. Larvae preferred to overwinter in soil under Persicaria maculosa near the edge of a river, while adults overwintered far from water and, rarely under tussock grasses on sandbars. The larvae of $A$. fulva cache the seeds of $P$. maculosa. Rearing $A$. fulva under field conditions revealed that this species takes 254-328 days complete its development, which includes the winter period.
\end{abstract}

\section{INTRODUCTION}

The study of the life cycles of ground beetles has a long history. The first data on biology of European species was published more than 150 years ago (Matalin, 2007). To date, the life cycles of many species of carabid are described and various ways of classifying the different types of development proposed (Larsson, 1939; Thiele, 1977; Paarmann, 1979; Matalin, 2007).

It is, however, known that the seasonal reproductive rhythms of carabid beetles are greatly affected by day length and temperature (Thiele, 1977; Ferenz, 1977). Hence, for the same species both individual characteristics of the life cycle and the whole life cycle differ depending on biotope specificity (Paarmann, 1979; Jørum, 1980; Refseth, 1980, 1986; Loreau, 1985; Niemelä et al., 1989; Matalin, 2006; Filippov, 2006a, b). Flexibility of life cycles is of great adaptive value and one of the major reasons for the successful dispersal and colonization by many species of carabids. Moreover, analysis of the patterns of development recorded along natural gradients make life cycles an important topic for discussions on the evolution among superspecific taxa (Thiele, 1977; Paarmann, 1979; Sota \& Ishikawa, 2004). To study adaptation, distribution and dispersal in Carabidae it is important to obtain information on the extent of the variation in the phenology of individuals of the same species from different locations. Detailed knowledge on the annual activity patterns of different species is also a necessary element in studies examining the structure of local assemblages of carabids (Müller, 1985;
Loreau, 1986; Niemela, 1989). Moreover, ground beetles may be good indicators of the ecological status of various habitats and their life cycle patterns of the condition of landscapes, and it is proposed that they be used for ecological monitoring (Irmler, 2003).

However, for many widespread species there is little quantitative information on their annual activity patterns, fecundity, rate of development, feeding habits and distribution of life stages. An example of such a species is Amara fulva (Coleoptera: Carabidae). A. fulva is a Palearctic species distributed across Europe to Asia Minor and east into western Siberia, and has been introduced into North America (Lindroth, 1968). It is a xerophilous species, which prefers to live in areas with open, dry ground, usually consisting of sand with sparse vegetation (Lindroth, 1992; Eversham \& Telfer, 1994; Kielhorn et al., 1999; Andersen, 2000). It is quite often recorded in arable and heath lands (Desender \& Bosmans, 1998; Helenius et al., 2001). This beetle is nocturnal, remains buried in the soil during the day (Lindroth, 1992). The data on the feeding behaviour of $A$. fulva adults are scarce and there is no information on the feeding behavior of the larvae. A. fulva adults, like many species of this genus, are omnivourous (Burmeister, 1939; Hengeveld, 1980; Sharova, 1981; Larochelle, 1990). In Europe it has a one-year life cycle, reproduces in late summer-autumn and hibernates as a both a larva and an adult (Lindroth, 1968; Hůrka \& Ducháč, 1980). In spite of the wide, but local distribution of this species its biology is studied poorly and is not well known. There is little information on fecundity, time of oviposition, rate of devel- 


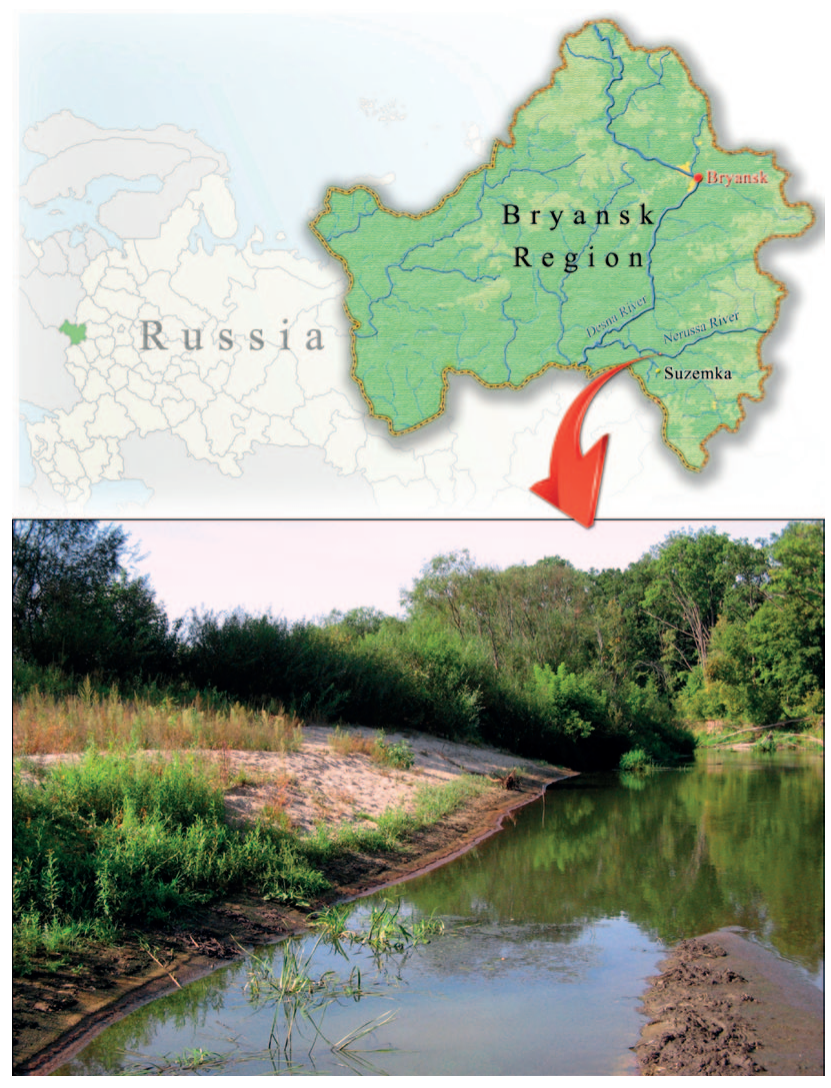

Fig. 1. The experimental plot on a sand bar in the Nerussa River (Bryansk region, Russian Federation).

opment, feeding behaviour and overwintering distribution. Moreover, its annual activity pattern, sex and age structures of populations may differ greatly at different locations.

This paper investigates life history patterns of $A$. fulva (Coleoptera: Carabidae) recorded in on the southwest forest zone on the East European Plain.

The objectives of the current study are: (1) determine the seasonal activity, sex and age structure of $A$. fulva, (2) estimate egg production in the field and development under laboratory condition and, (3) describe its distribution overwinter.

\section{MATERIAL AND METHODS}

\section{Study area}

The ground beetles used in this study were collected on the floodplain of the Nerussa River (Bryansk region, Russian Federation) in 2007 (Fig. 1).

The climate of the region is temperate continental with warm summers and cold-temperate winters. Average temperature is $18-19^{\circ} \mathrm{C}$ in July and $-7-9^{\circ} \mathrm{C}$ in January. Period over which the vegetation grows is about 180 days.

This study was carried out on a sandy bar in the River Nerussa $\left(52^{\circ} 23^{\prime} 56.59^{\prime \prime} \mathrm{N}, 34^{\circ} 7^{\prime} 16.22^{\prime \prime} \mathrm{E}\right)$. At low-water the sandbar is $7-10$ $\mathrm{m}$ wide and $70 \mathrm{~m}$ long. Silting of the shore line is insignificant. Seasonal renewal of substrate during spring flooding results in the formation of pioneer communities with a vegetation density of no more than $45 \%$. Alluvial species (Corispermum orientale, Persicaria maculosa, Xanthium albinum) predominate in these environments. Wet localities on sandbars were occupied by individual juvenile plants of Salix viminalis and S. triandra. There

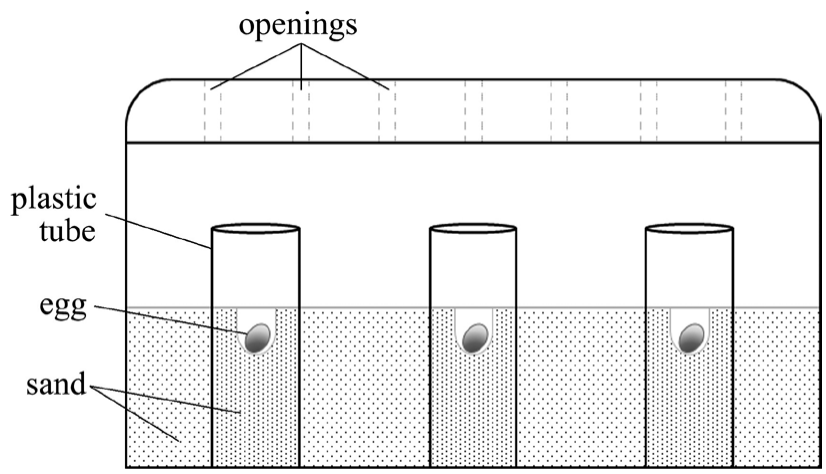

Fig. 2. Longitudinal section through the box used for incubating eggs of A. fulva.

were mature shrubs of $S$. viminalis and S. triandra, and separate specimens of $S$. alba on the distal end of the sandbar.

\section{Sampling methods}

Adults and larvae were collected using pitfall traps. On most occasions, 20 pitfall traps (plastic jars $70 \mathrm{~mm}$ in diameter and $85 \mathrm{~mm}$ deep filled with $4 \%$ formaldehyde as a killing and preserving agent) were set on the sandbar in the river from the third week of May till October. The distance between the traps was 3 meters. Individuals were removed from the traps every 10 days. Collections were sieved and transferred to $4 \%$ formaldehyde in the field, sorted under a microscope in the laboratory and stored in the same fluid for dissection.

On $23^{\text {rd }}$ to $25^{\text {th }}$ October, 2008, 30 samples $\left(0.0625 \mathrm{~m}^{2} ; 25 \times\right.$ $25 \mathrm{~cm}$ ) of soil were collected from different parts of the sandbar in order to determine the distribution of larvae and adults of $A$. fulva. Ten samples of soil were also collected along the banks of the river directly from under clumps of Persicaria maculosa (Polygonaceae) and ten from areas colonized by herbaceous plants but lacking $P$. maculosa. In addition ten samples were collected from the rear of the sandbar. The soil was sampled to a depth of $30 \mathrm{~cm}$.

\section{Seasonal activity}

Imago activity is expressed in terms of the numbers of individuals trapped per 100 trap-days (ind./100 t-d). The efficiency with which the larvae were caught is expressed as the number of specimens collected.

\section{Age determination}

The reproductive condition of the beetles was determined by dissecting the individuals and examining their gonads. Newly emerged (teneral) beetles were those with soft and pale coloured elytra (Wallin, 1988). The presence of corpora lutea in ovaries was used to distinguish between the new and overwintered generation (Van Dijk, 1972). Henceforth in the text non-overwintered and overwintered individuals are referred to as "young" and "old", respectively. There are, five stages in the development of the adults:

teneral (elytra are soft and pale coloured);

immature (ovaries are undeveloped; accessory glands of testicles are small and translucent);

mature young (ovaries contain mature oocytes; accessory glands are swollen and have a nacreous appearance);

mature old (in addition to mature eggs, ovaries contain a number of corpora lutea);

spent (ovaries have regressed and contain corpora lutea; accessory glands are greyish and disintegrating). 


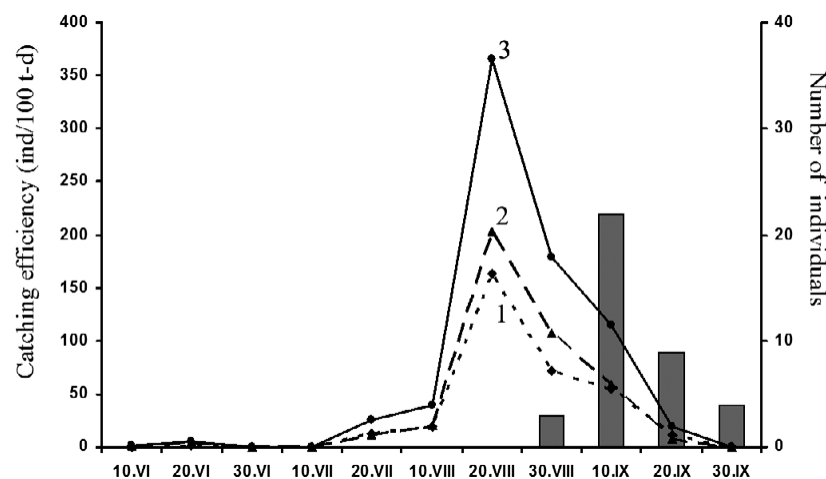

Fig. 3. Number (per 100 traps per 10 days) of adults and larvae of $A$. fulva caught in pitfall traps. 1 - females; 2 - males; 3 - total number of adults; grey columns - number of larvae caught by traps.

All mature females were dissected to determine the number of mature eggs in their ovaries. The mean number of eggs per ovary per female over a period of ten days was calculated.

\section{Laboratory study}

To determine the duration of embryonic, first-, second- and third instar larval development 76 eggs were collected from fertile females and reared. Thirty eight eggs were laid in early August (5-7 August; Group 1) and 38 eggs at the end of August (20-28 August; Group 2). The larvae that hatched from these two groups of eggs were reared separately. Eggs were kept together in a plastic box $(250 \mathrm{ml}, \mathrm{d}=80 \mathrm{~mm})$ that served as an incubator (Fig. 2). The incubator was filled with sand $(\mathrm{h}=20 \mathrm{~mm})$ moistened by spaying water. Plastic tubes $(l=30 \mathrm{~mm}, \mathrm{~d}=8 \mathrm{~mm})$ were embedded in the sand in the bottom of the incubator to provide cells for incubating the eggs, which were placed individually in each tube, after which the incubator was covered with a perforated lid. Newly emerged larvae were removed together with tubes and placed individually in glass jars $(30 \mathrm{ml})$ filled with moistened sand. Larvae were fed ripe seeds of $P$. maculosa. To monitor the stage of development of the beetles the jars were examined daily.

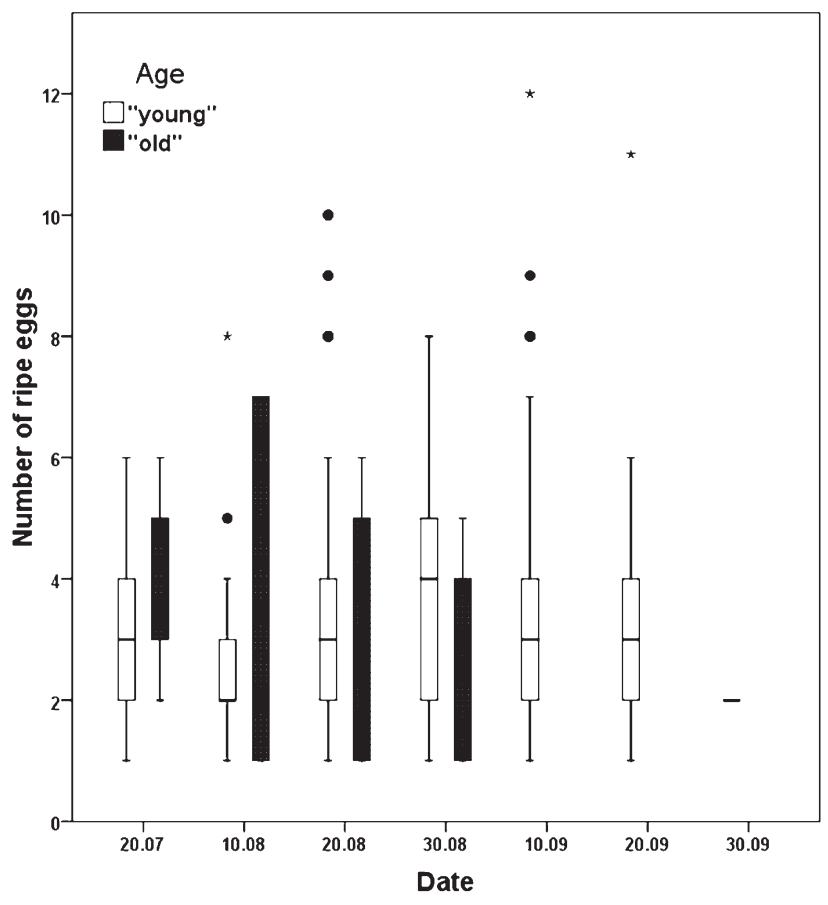

Fig. 4. Mean number of mature eggs in the ovaries of $A$. fulva. White columns - first time breeders ("young" females); black columns - repeat breeders ("old" females; asterisks - extreme values; black points - outliers.

As we did not keep third instar larvae in the laboratory during winter, the duration of the pupal stage was studied the following year by collecting 24 third instar larvae collected at the end of March from soil under P. maculosa. The duration of third instar larval development was calculated as: developmental time of laboratory reared third instar larvae plus developmental time of third instar larvae collected in the field the following year, which were kept individually in $30 \mathrm{ml}$ glass jars at natural outdoor temperatures.

TABLE 1. Seasonal occurrence in the experimental plot of adult individuals of $A$. fulva in different stages of development.

\begin{tabular}{|c|c|c|c|c|c|c|c|c|c|c|c|c|}
\hline \multirow{2}{*}{ Age } & \multicolumn{3}{|c|}{ June } & \multicolumn{3}{|c|}{ July } & \multicolumn{3}{|c|}{ August } & \multicolumn{3}{|c|}{ September } \\
\hline & $\mathrm{I}$ & II & III & $\mathrm{I}$ & II & III & $\mathrm{I}$ & II & III & $\mathrm{I}$ & II & III \\
\hline \multicolumn{13}{|c|}{ Females } \\
\hline Teneral & 1 & - & - & - & - & - & & - & - & - & - & - \\
\hline Immature & - & - & - & - & 12 & 49 & & 13 & 20 & 17 & 6 & - \\
\hline Mature young & - & - & - & - & 8 & 21 & & 101 & 112 & 94 & 17 & 1 \\
\hline Mature old & - & - & - & - & 3 & 2 & & 10 & 10 & - & - & - \\
\hline Spent & - & 2 & - & - & 3 & 7 & & 39 & - & - & - & - \\
\hline Total & 1 & 2 & - & - & 26 & 79 & & 163 & 142 & 111 & 23 & 1 \\
\hline \multicolumn{13}{|c|}{ Males } \\
\hline Teneral & - & 1 & - & - & - & - & & - & - & - & - & - \\
\hline Immature & - & - & - & - & 6 & 6 & & - & - & - & - & - \\
\hline Mature & - & - & - & - & 17 & 70 & & 180 & 211 & 117 & 15 & - \\
\hline Spent & 2 & 6 & - & - & 1 & 4 & & 23 & 4 & 1 & - & - \\
\hline Total & 2 & 7 & - & - & 24 & 80 & & 203 & 215 & 118 & 15 & - \\
\hline \multicolumn{13}{|c|}{ Larvae } \\
\hline First instar & - & - & - & - & - & - & & - & 3 & 10 & 3 & - \\
\hline Second instar & - & - & - & - & - & - & & - & - & 12 & 5 & 3 \\
\hline Third instar & - & - & - & - & - & - & & - & - & & 1 & 1 \\
\hline Total & - & - & - & - & - & - & & - & 3 & 22 & 9 & 4 \\
\hline
\end{tabular}




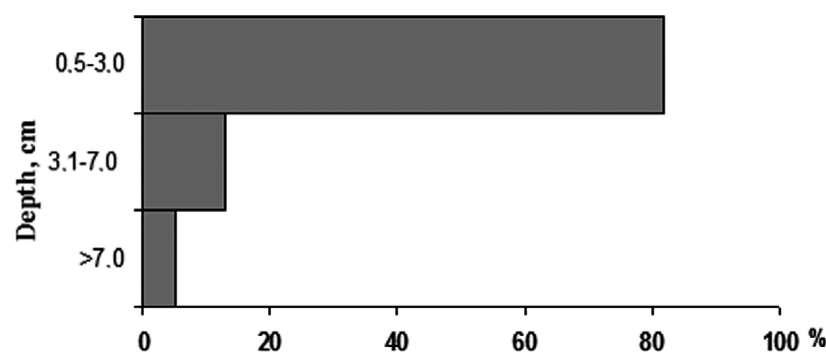

Fig. 5. Depth in the soil under P. maculosa of overwintering larvae of $A$. fulva.

Statistical analysis of the results was done using SPSS Statistics 17.0.1 software. In the text, the symbol " \pm " precedes standard deviations; NS - not significant.

\section{RESULTS}

\section{Seasonal activity}

Overall, 1212 adults (664 males and 548 females) and 38 larvae were caught by the pitfall traps. Based on the pitfall trap results, $A$. fulva is the most abundant species at the locality studied (43\% of the total number of carabids caught). A. fulva adults were active from the first week of June till October, with a single peak in activity in August (Fig. 3). Up to the third decade of July, imago activity was low (1.5 ind./10 t-d). But at this time, adults of $A$. fulva were often discovered when digging. During peak activity 20 ind./10 t-d were caught. The sex-ratio was males biased throughout the year $\left(\chi_{1}^{2}=11.1, P<0.001\right)$. Both sexes became active at the same time and followed the same trend.

Age composition of the population studied is presented along with the adult age groups and larvae in Table 1. From June onwards only spent and teneral beetles were caught by the pitfall traps. Immature and mature adults were recorded from the second half of July. At the end of August, more than $90 \%$ of the population was made up of mature adults. The percentage of repeatedly breeding females ("mature old") was 6.6\%. Immature individuals continued to be trapped right up to when the beetles became inactive (in October) and entered the overwintering stage.

Larvae of A. fulva were caught from the third week of August up until October and their peak activity was recorded in the first week of September (Fig. 3).

\section{Egg production}

There were mature eggs $(n=1292)$ in the ovaries over a period of 11 weeks (from the middle of July to the end of September). There was a similar temporal pattern in the activity of females and the number of mature eggs in their ovaries, however, this correlation is not significant (Spearman rank correlation coefficient $\left.r_{s}=0.6, N S\right)$. The number of mature eggs in their ovaries increased from the beginning of the oviposition period up to the end of August, after which it decreased to zero (Fig. 4). Maximum number of mature eggs in the ovaries of non-overwintering females was $3.69 \pm 1.82$. Female activity had a similar pattern, but peaked in mid-August (Fig. 3). On average, young females of $A$. fulva had more mature eggs in their ovaries than old females. The mean number of mature eggs in young and

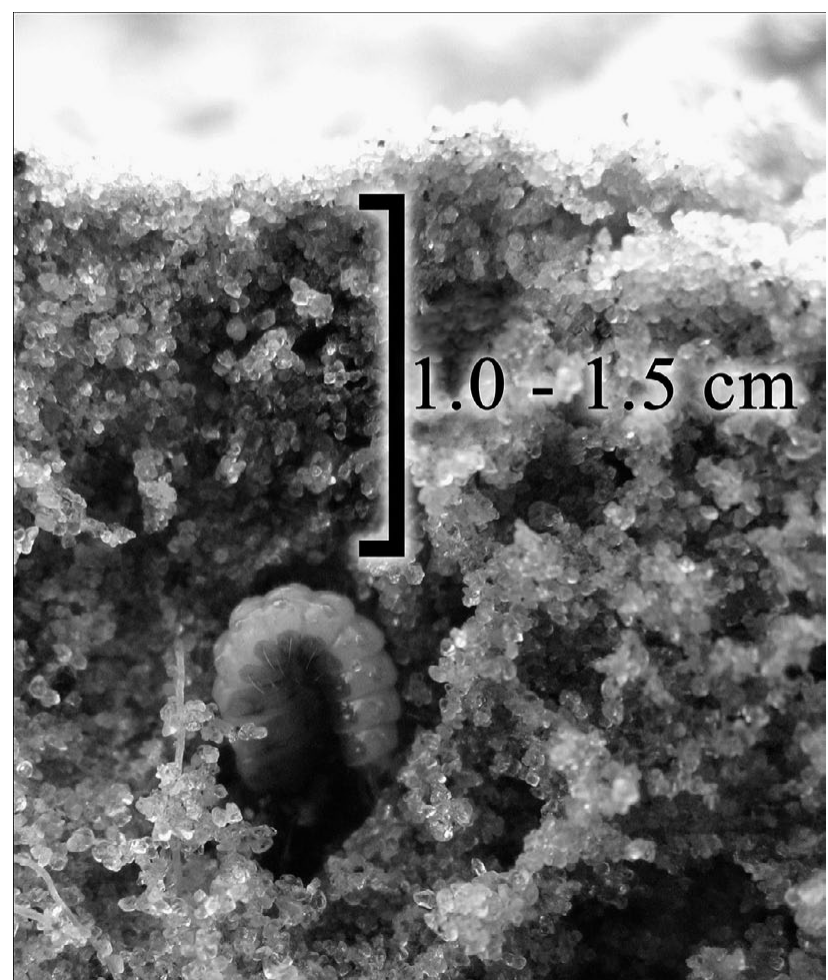

Fig. 6. Third instar larva of $A$. fulva overwintering in soil.

old females was $3.43 \pm 2.02$ and $3.08 \pm 1.87$, respectively ( $p>0.05$, NS). "Young" and "old" females had maxima of 12 and 7 eggs, respectively.

\section{Distribution of overwintering Amara fulva}

Soil sampled at the end of October indicated that A. fulva overwinters as larvae (primarily in the third instar) and adults. The sampling of soil under dry plants of $P$. maculo$s a$ resulted in the collection of 185 larvae. Mean abundance of larvae was $296.0 \pm 197.0 \mathrm{ind} . / \mathrm{m}^{2}(\mathrm{~N}=10)$. Minimum and maximum number of larvae in the soil samples $(0.0625$ $\mathrm{m}^{2}$ ) was 3 and 41, respectively. Most of the larvae (>80\%) were in the upper $3 \mathrm{~cm}$ of soil (Fig. 5).

There was no $P$. maculosa growing along the riverside and no larvae of $A$. fulva were recorded on the distal part of the sandbar.

TABLE 2. Duration of the different stages of preimaginal development of $A$. fulva reared in the laboratory. * Development was calculated as the time it took this species to reach the third instar when reared in the laboratory plus the developmental time of third instar larvae collected in the field the following year.

\begin{tabular}{|c|c|c|c|c|c|c|}
\hline Instar & & $\begin{array}{l}\mathrm{N} \text { (initial number } \\
\text { of individuals) }\end{array}$ & $\begin{array}{r}\text { Mean } \\
\text { (days) }\end{array}$ & SD & $\begin{array}{l}\operatorname{Min} / \\
\operatorname{Max}\end{array}$ & $\begin{array}{c}\text { Survival } \\
(\%)\end{array}$ \\
\hline \multirow[t]{2}{*}{ Egg } & G1 & 38 & 7.3 & 0.7 & $7 / 9$ & 94.7 \\
\hline & G2 & 38 & 8.4 & 1.1 & $6 / 10$ & 79.0 \\
\hline \multirow[t]{2}{*}{ First instar } & G1 & 36 & 11.9 & 1.1 & $9 / 13$ & 86.1 \\
\hline & G2 & 30 & 10.3 & 1.4 & $8 / 12$ & 63.3 \\
\hline \multirow[t]{2}{*}{ Second instar } & G1 & 31 & 16.6 & 4.5 & $13 / 28$ & 64.5 \\
\hline & $\mathrm{G} 2$ & 19 & 13.0 & 2.4 & $11 / 19$ & 89.3 \\
\hline Third instar* & & 24 & 228 & - & - & 83.3 \\
\hline Pupa & & 20 & 13.2 & 1.7 & $10 / 17$ & 95.0 \\
\hline
\end{tabular}


The winter quarters of larvae are undersoil cavities 5-6 $\mathrm{mm}$ in diameter (Fig. 6). Each cavity examined $(\mathrm{N}=70)$ contained seed coats (testa) and/or intact seeds of $P$. maculosa. Most of the seed material $(\mathrm{N}=275)$ consisted of seed coats with only a few $(\mathrm{N}=7)$ intact seeds. The number of seed coats varied widely (from 1 to 22), but most cavities contained only $1-3$ seed coats (mean $=4.03 \pm 3.85$ ). Seed coats were pressed into the walls of the cavity. Some cavities were devoid of any seed material. All larvae were coiled up on the dorsal side of the body. In the samples collected from under tussock grasses on the distal part of the sandy bar there were five adult $A$. fulva. This indicates that adults and larvae of this species may overwinter in different locations.

\section{Laboratory rearing}

Embryonic development of Group $1 \mathrm{~A}$. fulva lasted on average $7.3 \pm 0.67$ days and of Group 2, $8.4 \pm 1.1$ days (Table 2). The durations of development of first-instar larvae were 11.2 \pm 1.07 days (Group 1) and 10.3 \pm 1.4 days (Group 2) and second-instar larvae 16.6 \pm 3.36 days (Group 1) and $13.0 \pm 2.4$ (Group 2). Third-instar larvae collected in early spring were not active on the soil surface, but in burrows with pupal chambers in which they pupated from $5^{\text {th }}$ to $24^{\text {th }}$ May. Calculated duration of development of third-instar larvae (including winter period) was 219-260 days. Thus, all larvae overwintered, and completed their development the following year.

The pupal stage lasted 10-17 days and adults emerged from the end of May until the beginning of June. Newly emerged beetles stayed in the cavities for 3-4 days and then appeared on the soil surface. Thus, development from egg to adult (including the winter period) took 254-328 days.

\section{DISCUSSION}

The seasonal activity of $A$. fulva recorded in this study differs from that reported for other parts of this species distribution. According to our data, A. fulva adults were active from June till October with a single peak in August. A similar period of activity is reported in Britain and Ireland (Luff, 2007). In farmlands of south-eastern Norway, adults of $A$. fulva are recorded from July till August (Andersen, 1985). In southern Sweden A. fulva is active from March till October with an activity peak in June (Lindroth, 1992). However, in Czechoslovakia there are two peaks of activity (June - hatching of the new generation and August-September - reproduction) (Hůrka \& Ducháč, 1980) and they are active from April to the end of September. Probably, these differences are due to the fact that only qualitative data on the annual activity of adults was used in previous studies.

Data on larval activity are scarce. Larsson (1939) reports larvae in December and May in Denmark. Hůrka \& Ducháč (1980) found two third instar larvae in Central Bohemia in the middle of October, Emden (1942) reports one second instar larva and six third instar larvae at the beginning of November in Poland and four third instar larvae in April and May in Germany (Riesa, Saxonia). Taking into consideration that we sampled the larvae by pitfall trapping our data coincides with the reports mentioned above.

In the literature A. fulva is characterized as an autumnbreeding species. However, in most parts of Europe it behaves as an autumn breeder with a thermic hibernation parapause as larva and no dormancy in the course of adult development (Thiele, 1977). In our study teneral adults emerged in the laboratory from the end of May to early June. At this time they were commonly collected from soil by digging, but were not caught by the pitfall traps. It is suggested that the adults of $A$. fulva undergo an aestivation parapause during which they remain inactive. The factors causing early summer inactivity are unclear. Probably, it is induced by photoperiod or a shortage of the preferred food.

Compared to earlier data (Hůrka \& Ducháč, 1980), duration of the preimaginal stages of $A$. fulva is somewhat different. According to our study, duration of egg development coincides with that recorded in previous studies (7-8 days), but the duration of the first instar larvae is only half of that previously reported (10-11days vs 20 days). Laboratory observations indicate that, despite a relatively long oviposition period, larvae that hatched early did not complete their development in the current year, but hibernated and pupated the following year. Thus, with respect to duration, A. fulva is a univoltine species; the beetles of the new generation appear every year, because the overwintered individuals reproduce in the same season. Third instar larvae are the main overwintering stage in this species. However, immature adults were trapped over the whole period of this study and hibernate together with larvae. Some of beetles of the new generation that developed from the overwintered larvae and hibernated in an immature stage prior to reproducing. Hibernation of immature adults increases the duration of development to two years. A similar life cycle is recorded for Carabus problematicus, another species with summer-autumnal reproduction (Houston, 1981). According to Matalin's typology (2007), the life cycle includes some part of the population of beetles of the new generation that appear every year. Taking into account the seasonality and repeatability of reproduction (semelparous or iteroparous nature of species) the life cycle of $A$. fulva in the area studied might be characterized as facultativebiennial - summer-autumn - iteroparous (Matalin, 2007).

Field and laboratory observations indicate that $A$. fulva females became gravid and started laying eggs from the middle of July. At this time, P. maculosa, was the dominant plant on the sand bar and set its seed somewhat later, which probably serve as a main food source for the larvae. It is suggested that newly hatched larvae have to manage without seeds of the present year. Probably, there are three ways for the larvae to tolerate these unfavorable conditions. First, newly hatched individuals could starve for a while. Luff (1994) and Wallin et al. (1992) report that firstinstar larvae of ground beetles can survive up to two weeks and even more without food. The second way is to feed on seeds buried the previous year. According to some authors, buried seeds might be more preferable than fresh ones and important when few plants produce seeds (Martinková et 
al., 2006). The third and most likely explanation is that A. fulva, like most carabids is polyphagous. Analysis of gut contents revealed that adults of A. fulva consume species of Formicidae, Lycosidae, Aphididae and other families (Hengeveld, 1980). However, it is quite possible, that shortage of food inhibits the development of larvae; delaying emergence of a new generation of adults results in part of the population having a biennial life cycle.

Soil sampling revealed that the overwintering distribution of the different life stages differed; larvae were found near water, under $P$. maculosa, where they were abundant (296 \pm 197 individuals $/ \mathrm{m}^{2}$ ), but adults were found elsewhere, indicating that adults and larvae occupied different overwintering sites. A similar distribution of larvae on the floodplain of the Kizu River is reported by Yamazaki et al. (1999). They report that adults of Harpalus are found in microhabitats away from rivers, but their larvae overwinter in marshy ground near running water. In particular, larvae of Harpalus capito occur abundantly (density 37.0 individuals $/ \mathrm{m}^{2}$ ) under weeds such as Polygonum longisetum and Rorippa indica. Yamazaki et al. (1999) suggest that overwintering near water is not harmful for larvae, because floods occur in summer in that region, when beetles are active and can easily escape inundation. However, in our study flooding occurred at the end of March, when larvae were not active and would as a consequence be submerged for a long time. According to some authors (Murdock, 1967; Hatteland et al., 2008), larvae are more sensitive to disturbance than adults and therefore choose more stable habitats for overwintering. On the other hand, Zerm and Adis (2001) report that adult tiger beetles (Phaeoxantha clugii, P. lindemannae and Tetracha spinosa) inhabiting Central Amazonian floodplains can survive being submerged during flooding for no more $10 \mathrm{~h}$ whereas the larvae of this species can survive for 3.5 months. This may be possible because beetles can depress their metabolism and utilize anaerobic metabolic pathways (Hoback \& Stanley, 2001).

Adults of A. fulva overwintered on the distal parts of sandbars under tussock grasses. According to Andersen $(2005,2006)$, dispersal of riparian ground beetles to adjacent, non-innundated habitats of floodplains is an evolutionary adaptation for surviving in such areas. Insects that overwinter in those parts of the floodplain where tussock grasses occur are protected from sharp decreases in temperature (Thomas et al., 1992).

Most larvae of A. fulva were found in the top few centimeters of soil, and thus could be damaged by freezing during winter. However, it is known that most species that occur in temperate cold continental area have supercooling points that are lower than the winter temperatures they are likely to experience (Turnock \& Fields, 2005). In addition, survival is better near the surface as those insects overwintering slightly deeper do not become sufficiently acclimatized to cold conditions to survive the periodic thawing and refreezing of the substrate (Guzman \& Peterson, 1986). Furthermore, a covering of snow on the soil is frequently an important factor in insect survival. It is known that some species of insects remain active at low temperatures and move deeper in the overwintering site during early winter (Danks, 1991; Leather et al., 1993). This is recorded, for example, in Harpalus erraticus which moves down in the soil as temperature decreases (Kirk, 1972, 1974). Larvae of Patrobus atrorufus (Thiele, 1964), Nebria salina (Lehmann, 1965), N. brevicolls (Heydemann, 1962) remain active in winter. The larvae of Pterostichus niger and P. vulgaris are still active at $-1^{\circ} \mathrm{C}$ (Thiele, 1977). Soil sampling for A. fulva larvae was performed at the end of October, when day temperatures are somewhat high and above the value of the cold stupor point (Block, 1990). Probably, over the course of several days they could burrow deep in the soil and then remain stationary overwinter.

Late autumn sampling revealed that the soil cavities occupied by third instar larvae contained cached seeds of $P$. maculosa. Seed-caching behaviour has only been reported for the larvae of species of Harpalus and Ophonus (Kirk, 1972; Brandmayr \& Brandmayr, 1975; Alcock, 1976; Luff, 1980, Hartke et al., 1998). Burrowing larvae prefer the seed of particular species and these seed preferences are manifested by the seed caches in their burrows (Alcock, 1976). The burrows of ground beetle larvae vary in size depending on larval age and species, but in all cases they are vertical tubes of different lengths. Third instar larvae of $A$. fulva do not dig vertical burrows like other seed-caching species, but create a cell into the wall of which they insert seeds of P. maculosa. The seeds of other species of plant were not recorded in their cells. Seed-caching behaviour may have an adaptive value since it significantly reduces the time the larva spends on the bare soil surface, where it has no protection against enemies (Brandmayr et al., 2009).

Because A. fulva occurs only in the riverside zone it is possible to evaluate its vulnerability. On the one hand, heterogeneity within the population increases its stability, prevents abrupt changes in abundance and reduces the risk of extinction. On the other hand, both larvae and adults of A. fulva do not migrate to adjacent areas for overwintering, but remain in the riverside zone. In addition, as most of the larvae overwinter close to $P$. maculosa they are more vulnerable. So, this must be taken into account in situations where humans alter the natural flood cycle by damming and controlled releases for irrigation or hydropower. This practice leads ultimately to a loss of habitat for A. fulva, which is typically found in open sandy sites.

ACKNOWLEDGEMENTS. We thank I.Kh. Sharova for helpful suggestions and critical comments, and P. Saska for literature.

\section{REFERENCES}

Alcock J. 1976: The behavior of the seed-collecting larvae of a carabid beetle (Coleoptera). — J. Nat. Hist. 10: 367-375.

Andersen A. 1985: Carabidae and Staphylinidae (Col.) in swede and carrot fields in northern and south-western Norway. Fauna Norv. (B) 32: 12-27.

ANDERSEN J. 2000: What is the origin of the carabid beetle fauna of dry, anthropogenic habitats in western Europe? - J. Biogeogr. 27: 795-806. 
ANDERSEN J.M. 2005: Riparian beetles, a unique, but vulnerable element in the fauna of Fennoscandia. - Biodiv. Conserv. 14: $3497-3524$.

ANDERSEN J.M. 2006: Mechanisms in the shift of riparian ground beetle (Carabidae) between reproduction and hibernation habitat. - J. Insect Behav. 19: 545-558.

BLOCK W. 1990: Cold tolerance of insects and other arthropods. - Phil. Trans. R. Soc. Lond. (B) 326: 613-633.

Brandmayr T.Z. \& Brandmayr P. 1975: Biologia di Ophonus puncticeps Steph. Cenni sulla fitofagia delle larve e loro etologia (Coleoptera, Carabidae). - Ann. Fac. Sci. Agr. Univ. Stud. Torino 9: 421-430.

Brandmayr P., Bonacci T., Giglio A., Talarico F.F. \& BrandMAYR T.Z. 2009: The evolution of defence mechanisms in carabid beetles: a review. In Casellato S., Burighel P. \& Minelli A. (eds): Life and Time: The Evolution of Life and its History. Cleup, Padova, pp. 25-43.

Burmeister F. 1939: Biologie, Ökologie und Verbreitung der Europäischen Käfer, I. Band: Adephaga, Caraboidea. Hans Goecke, Krefeld, 206 pp.

DANKs H.V. 1991: Winter habitats and ecological adaptations for winter survival. In Lee R.E. \& Denlinger D.L. (eds): Insect at Low Temperature. Chapman and Hall, New York, London, pp. 231-259.

Desender K. \& Bosmans R. 1998: Ground beetles (Coleoptera, Carabidae) on set-aside fields in the Campine region and their importance for nature conservation in Flanders (Belgium). Biodiv. Conserv. 7: 1485-1493.

EMDEN F.I. 1942: A key to the genera of larval Carabidae (Coleoptera). — Trans. R. Entomol. Soc. Lond. 92: 1-99.

Eversham B.C. \& Telfer M.G. 1994: Conservation value of roadside verges for stenotopic heathland Carabidae: corridors or refugia? - Biodiv. Conserv. 3: 538-545.

FERENZ H.-J. 1977: Two-step photoperiodic and hormonal control of reproduction in the female beetle, Pterostichus nigrita. - J. Insect Physiol. 23: 671-676.

FILIPPOv B.Yu. 2006a: Seasonal aspects of the life cycles of Carabus granulatus and C. glabratus (Coleoptera, Carabidae) in the Northen Taiga. - Entomol. Rev. 86: 751-759.

FILIPPOv B.YU. 2006b: Seasonal aspects of life cycles in Calathus melanocephalus and C. micropterus in the Northen Taiga. Entomol. Rev. 86: 901-909.

Guzman D.R. \& Petersen J.J. 1986: Overwintering of fifth fly parasites (Hymenoptera: Pteromalidae) in open silage in eastern Nebraska. - Environ. Entomol. 15: 1296-1300.

Hartke A., Drummond F.A. \& Liebman M. 1998: Seed feeding, seed caching, and burrowing behaviours of Harpalus rufipes DeGeer larvae (Coleoptera: Carabidae) in the Maine potato agroecosystem. - Biol. Contr. 13: 91-100.

Hatteland B.A., Pedersen T.N., Mortensen F. \& Solhøy T. 2008: Species-area relations and island distribution of carabid beetles (Coleoptera, Carabidae) on small islands of the coast of western Norway. - Norw. J. Entomol. 56: 73-80.

Helenius J., Holopainen J.K., Huusela-Veistola E., Kurppa S., PoKKI P. \& VARIS A.-L. 2001: Ground beetle (Coleoptera, Carabidae) diversity in Finnish arable land. - Agric. Food Sci. Finl. 10: 261-276.

Hengeveld R. 1980: Polyphagy, oligophagy and food specialization in ground beetles (Coleoptera, Carabidae). - Neth. J. Zool. 30: 564-584.

Heydemann B. 1962: Die biozönotische Entwicklung vom Vorland zum Koog. Vergleichend-ökologische Untersuchungen an der Nordseeküste. II. Teil: Käfer (Coleoptera). — Abh. Math.Naturw. Kl. Akad. Wiss. Mainz 11: 765-964.
Hoback W.W. \& Stanley D.W. 2001: Insects in hypoxia. - J. Insect Physiol. 47: 533-542.

Houston W.W.K. 1981: The life cycles and age of Carabus glabratus Paykull and C. problematicus Herbst. (Col.: Carabidae) on Moorland in Northern England. - Ecol. Entomol. 6: 263271.

HŮRKA K. \& DuCHÁČ V. 1980: Larvae and the breeding type of the central European species of the subgenera Bradytus and Pseudobradytus (Coleoptera, Carabidae, Amara). - Věst. Čs. Spol. Zool. 44: 166-182.

IRMLER U. 2003: The spatial and temporal pattern of carabid beetles on arable fields in northern Germany (Schleswig-Holstein) and their value as ecological indicators. - Agric. Ecosyst. Environ. 98: 141-151.

JøRUM P. 1980: Life cycles and annual activity patterns of Pterostichus melanarius (Illig.) and P. niger (Schall.) (Coleoptera: Carabidae) in a Danish beech wood. - Entomol. Medd. 48: $19-25$.

Kielhorn K.-H., Keplin B. \& Hüttl R.F. 1999: Ground beetle communities on reclaimed mine spoil: effects of organic matter application and revegetation. - Plant Soil 213: 117-125.

KIRK V.M. 1972: Seed-caching by larvae of two ground beetles, Harpalus pensylvanicus and H. erraticus. - Ann. Entomol. Soc. Am. 65: 1426-1428.

KIRK V.M. 1974: Biology of a ground beetle, Harpalus erraticus. - Ann. Entomol. Soc. Am. 67: 24-28.

Larochelle A. 1990: The food of carabid beetles (Coleoptera: Carabidae, including Cicindelinae). — Fabreries (Suppl. 5): $132 \mathrm{pp}$.

LARSSON S.G. 1939: Entwicklungstypen und Entwicklungszeiten der dünischen Carabiden. - Entomol. Medd. 20: 277-560.

Leather S.R., Walters K.F. \& Bale J.S. 1993: The Ecology of Insect Overwintering. Cambridge University Press, Cambridge, $255 \mathrm{pp}$.

LeHMANN H. 1965: Ökologische Untersuchungen über die Carabidenfauna des Rheifers in der Umgebung von Köln. - Z Morphol. Oekol. Tiere 55: 597-630.

Lindroth C.H. 1968: The ground beetles of Canada and Alaska. Pt. 5. - Opusc. Entomol. Suppl. 33: 649-944.

Lindroth C.H. 1992: Ground Beetles of Fennoscandia. A Zoogeographic Study. Part I. Specific Knowledge Regarding the Species. Amerind, Washington, $630 \mathrm{pp}$.

LOREAU M. 1985: Annual activity and life cycles of carabid beetles in two forest communities. - Ecography 8: 228-235.

LOREAU M. 1986: Niche differentiation and community organization in forest carabid beetles. In den Boer P.J., Luff M.L., Mossakowski D. \& Weber F. (eds): Carabid Beetles: Their Adaptations and Dynamics. Gustav Fisher, Stuttgart, pp. 465-487.

LuFF M.L. 1980: The biology of the ground beetle Harpalus rufipes in a strawberry field in Northumberland. - Ann. Appl. Biol. 94: 153-164.

LuFF M.L. 1994: Starvation capacities of some carabid larvae. In Desender K., Dufrene M., Loreau M., Luff M.L., Maelfait J.-P. (eds): Carabid Beetles, Ecology and Evolution. Series Entomologica 51. Kluwer, Dordrecht, pp. 171-175.

LufF M.L. 2007: The Carabidae (Ground Beetles) of Britain and Ireland. Handbooks for the Identification of British Insects. Vol. 4. Part 2 (2 $2^{\text {nd }}$ ed.). Royal Entomological Society. St. Albans \& Field Studies Council, Shrewbury, 252 pp.

Martinková Z., SASKa P. \& HonĚK A. 2006: Consumption of fresh and buried seed by ground beetles (Coleoptera: Carabidae). - Eur. J. Entomol. 103: 361-364.

Matalin A.V. 2006: Geographic variability of the life cycle in Pterostichus melanarius (Coleoptera, Carabidae). - Entomol. Rev. 86: 409-422. 
Matalin A.V. 2007: Typology of life cycles of ground beetles (Coleoptera, Carabidae) in Western Palaearctic. - Entomol. Rev. 87: 947-972.

MuRDOCK W.W. 1967: Life history patterns of some British Carabidae (Coleoptera) and their ecological significance. — Oikos 18: $25-32$.

MÜLLER J.K. 1985: Konkurrenzvermeidung und Einnischung bei Carabiden (Coleoptera). — Z. Zool. Syst. Evol. Forsch. 23: 299-315.

Niemelä J., Haila Y., Halme E., Pajunen T. \& Punttila P. 1989: The annual activity cycle of carabid beetles in the southern Finnish taiga. - Ann. Zool. Fenn. 26: 35-41.

PaArmann W. 1979: Ideas about the evolution of the various annual reproduction rhythms in carabid beetles of the different climatic zones. - Misc. Pap. L.H. Wagen. 18: 119-132.

ReFseth D. 1980: Differences in seasonal activity pattern and breeding time of Patrobus atrorufus (Carabidae) in central Norway. - Holarct. Ecol. 3: 87-90.

Refseth D. 1986: Phenological adaptations in Patrobus atrorufus and $P$. assimilis (Col., Carabidae). - Fauna Norv. 33: 57-63.

Sharova I.CH. 1981: Life Forms of Carabids. Nauka, Moscow, $360 \mathrm{pp}$.

Sota T. \& Ishikawa R. 2004: Phylogeny and life-history evolution in Carabus (subtribe Carabina: Coleoptera, Carabidae) based on sequences of two nuclear genes. - Biol. J. Linn. Soc. 81: $135-149$.

Thiele H.U. 1964: Experimentelle Untersuchungen über die Ursachen der Biotopbindung bei Carabiden. - Z. Morphol. Oekol. Tiere 53: 387-452.
ThIele H.U. 1977: Carabid Beetles in their Environments. Springer, Berlin, 369 pp.

Thomas M.B., Mitchell H.J. \& Wratten S.D. 1992: Abiotic and biotic factors influencing the winter distribution of predatory insects. - Oecologia 89: 78-84.

TURNOCK W.J. \& Fields P.G. 2005: Winter climates and coldhardiness in terrestrial insects. - Eur. J. Entomol. 102: 561-576.

VAN DiJK T.S. 1972: The significance of the diversity in age composition of Calathus melanocephalus L. (Col., Carabidae) in space and time at Schiermonnikoog. - Oecologia (Berl.) 10: 111-136.

Wallin H. 1988: Mandible wear in the carabid beetle Pterostichus melanarius in relation to diet and burrowing behaviour. - Entomol. Exp. Appl. 48: 43-50.

Wallin H., Chiverton P.A., Еквom B.S. \& Borg A. 1992: Diet, fecundity and egg size in some polyphagous predatory carabid beetles. - Entomol. Exp. Appl. 65: 129-140.

Yamazaki K., SugiURa S. \& KawamuRa K. 1999: Overwintering ground beetle assamblages along Kizu River, Kyoto. - Entomol. Sci. 2: 33-40.

Zerm M. \& AdIS J. 2001: Further observations on the natural history and survival strategies of riverine tiger beetles (Coleoptera: Cicindelidae) from open habitats in central Amazonian floodplains (Brazil). - Ecotropica 7: 115-137.

Received January 3, 2014; revised and accepted June 12, 2014 Prepublished online October 16, 2014 